Elsevier

GENE 03253

\title{
Structure and expression of the human gene encoding plasminogen activator inhibitor, PAI-1
}

(Primer extension analysis; genomic library; serine protease inhibitor; glycoproteins; promoter regions; serpins; phage $\lambda$ vectors; introns; cat gene; Alu repeat)

\section{Marie Follo and David Ginsburga,b}

Departments of ${ }^{a}$ Human Genetics and ${ }^{b}$ Internal Medicine, and ${ }^{b}$ Howard Hughes Medical Institute, University of Michigan Medical School, Ann Arbor, MI 48109-0650 (U.S.A.)

Received by J.L. Slightom: 1 May 1989

Revised: 18 July 1989

Accepted: 22 July 1989

\section{SUMMARY}

The gene (pail) encoding human plasminogen activator inhibitor, PAI-1 was cloned from a $\lambda$ EMBL3 genomic library and was found to span approx. $12 \mathrm{~kb}$ and to contain eight introns. Primer extension and $\mathrm{S} 1$ nuclease analyses both showed the transcription start point to be located $142 \mathrm{nt}$ upstrean from the start codon. The 5 '-flanking region was sequenced and found to contain a TATA box, but no CAAT sequence. When a fragment containing $730 \mathrm{nt}$ of $5^{\prime}$-untranslated region was placed upstream from a promoterless cat gene, it was shown to function as a promoter when transfected into COS cells. Northern-blot analysis was consistent with low level expression of the endogenous pail gene in COS cells. When the pail gene structure was compared to those of other members of the serine-protease-inhibitor encoding gene family, little conservation of intron positions was observed.

\section{INTRODUCTION}

Plasminogen activators are serine proteases which are able to convert the inactive plasminogen into the active protease plasmin. Plasminogen activation is involved in many biological processes such as

Correspondence to: Dr. D. Ginsburg, Howard Hughes Medical Institute, University of Michigan, 1150 West Medical Center Dr., Ann Arbor, MI 48109-0650 (U.S.A.) Tel. (313)747-4808; Fax (313)936-9353.

Abbreviations: aa, amino acid(s); AMV, avian myeloblastosis virus; bp, base pair(s); cat, gene encoding $\mathrm{Cm}$ acetyltransferase; cDNA, DNA complementary to RNA; cpm, counts/min; Cm, chloramphenicol; dNTP, deoxyribonucleoside triphosphate; tumorigenesis, embryogenesis, and tissue repair. However, it has been most completely studied for its role as the central step in the activation of the fibrinolytic system (Erickson et al., 1985).

The major form of plasminogen activator inhibitor found in human plasma is PAI-1 (for review see

ECGF, endothelial cell growth factor; HUVEC, human umbilical vein endothelial cell; IL-1, interleukin-1; kb, kilobase(s) or $1000 \mathrm{bp}$; nt, nucleotide(s); oligo, oligodeoxyribonucleotide; PAI-1, plasminogen activator inhibitor-1; pail, gene (DNA) encoding PAI-1; PCR, polymerase chain reaction; RSV, Rous sarcoma virus; serpin, serine protease inhibitor; SSC, $0.15 \mathrm{M}$ $\mathrm{NaCl} / 0.015 \mathrm{M} \mathrm{Na}_{3} \cdot$ citrate pH 7.6; TGF $\beta$, transforming growth factor $\beta$; TNF $\alpha$, tumor necrosis factor $\alpha ; t s p$, transcription start point(s). 
Loskutoff et al., 1989). PAI-1 is also found in platelets, endothelial cells, hepatoma cells, fibrosarcoma cells, mesothelial cells, and recently as a major component of the extracellular matrix. Vascular endothelial cells may represent the major site of synthesis for plasma PAI-1 (Loskutoff et al., 1989).

Several groups have cloned full-length pail cDNA (Ginsburg et al., 1986, Ny et al., 1986, Pannekoek et al., 1986, Andreasen et al., 1986). In human cells PAI-1 mRNA occurs in two sizes, $2.3 \mathrm{~kb}$ and $3 \mathrm{~kb}$, which differ only in the length of their 3 '-untranslated regions. Both mRNAs encode a $42-45-\mathrm{kDa}$ polypeptide which displays sequence similarity to other members of the serpin gene family. The human pail gene has been mapped to chromosome 7 (Ginsburg et al., 1986; Klinger et al., 1987).

The regulation of pail gene expression is complex. In HUVECs, PAI-1 activity is induced by substances such as thrombin, endotoxin, IL-1, TNF $\alpha$ and TGF $\beta$, and decreased by protein $C$ and heparin with ECGF. Expression of pail has also been shown to be induced by glucocorticoids in hepatoma and fibrosarcoma cells (Loskutoff et al., 1989).

We have used a PAI-1 cDNA probe to screen a human genomic library and have isolated overlapping clones which contain the pail gene. The exon structure and the $t s p$ were determined. A fragment containing $730 \mathrm{bp}$ of 5 '-flanking sequence was found to act as a promoter when transfected into COS cells. The gene structure of PAI-1 was compared to that of other serpins.

\section{MATERIALS AND METHODS}

\section{(a) Genomic cloning}

Approximately $2 \times 10^{6}$ recombinant clones from an amplified partial Sau3A human genomic library (obtained from P. Venta, University of Michigan) constructed in the $\lambda$ EMBL3 vector (Frischauf et al., 1983) were screened by hybridization to the ${ }^{32} \mathrm{P}$ labeled 2-kb EcoRI insert fragment of cDNA clone PAIB6 (Ginsburg et al., 1986). Four overlapping clones containing pail gene sequences were identified. Restriction fragments were subcloned into pGEMblue (Promega) and a detailed restriction map was constructed by standard methods (Maniatis et al., 1982). Probes were radiolabeled using the random hexamer method (Feinberg and Vogelstein, 1983). Sequencing was by the dideoxy method (Sanger et al., 1977) using Sequenase (U.S. Biochemical Corporation). Oligo sequencing primers were synthesized based on the PAI-1 cDNA sequence designed to sequence across the splice junctions as reported by Loskutoff et al. (1987).

\section{(b) Polymerase chain reaction}

Reactions were performed as previously described (Ginsburg et al., 1989). Either $100 \mathrm{ng}$ of the $\lambda$ EMBL3 phage clone 4A DNA, $100 \mathrm{ng}$ of control plasmid DNA, or $100 \mathrm{ng}$ of normal genomic DNA were added to each reaction mix in addition to 0.02 $A_{260}$ of each 30 -mer oligo primer. Taq polymerase (Cetus) was used according to the manufacturer's instructions. PCR conditions were $94^{\circ} \mathrm{C}$ for $1 \mathrm{~min}$, $15 \mathrm{~s}$, followed by $72^{\circ} \mathrm{C}$ for $4 \mathrm{~min}$ repeated for 30 cycles. The oligos used for intron 3 were the following. (3A) GATGAGATCAGCACCACAGACGCGATCTTC, PAI-1 cDNA positions 334-363 (Ginsburg et al., 1986), and (3B) 5'-GCACAGAGACAGTGCTGCCGTCTGATTTGT, complementary to positions 638 through 667 . Oligos for intron 4 were the following. (4A) 5 ' -ACTCCCTTCCCCGACTCCAGCACCCACCGC, located from nt 598-627; and (4B) 5'-GGTGTCCCCGTGGTAGGGCAGTTCCAGGAT, complementary to nt 736-765.

\section{(c) Computer analysis}

Alignment of serpin aa sequences was performed using the Needleman-Wunsch (1970) algorithm through the Sequence Analysis Software Package (Genetics Computer Group at the University of Wisconsin).

\section{RESULTS AND DISCUSSION}

\section{(a) Gene cloning}

A human genomic library in $\lambda E M B L 3$ was screened with a full-length human cDNA clone. Four overlapping phage clones were isolated and 


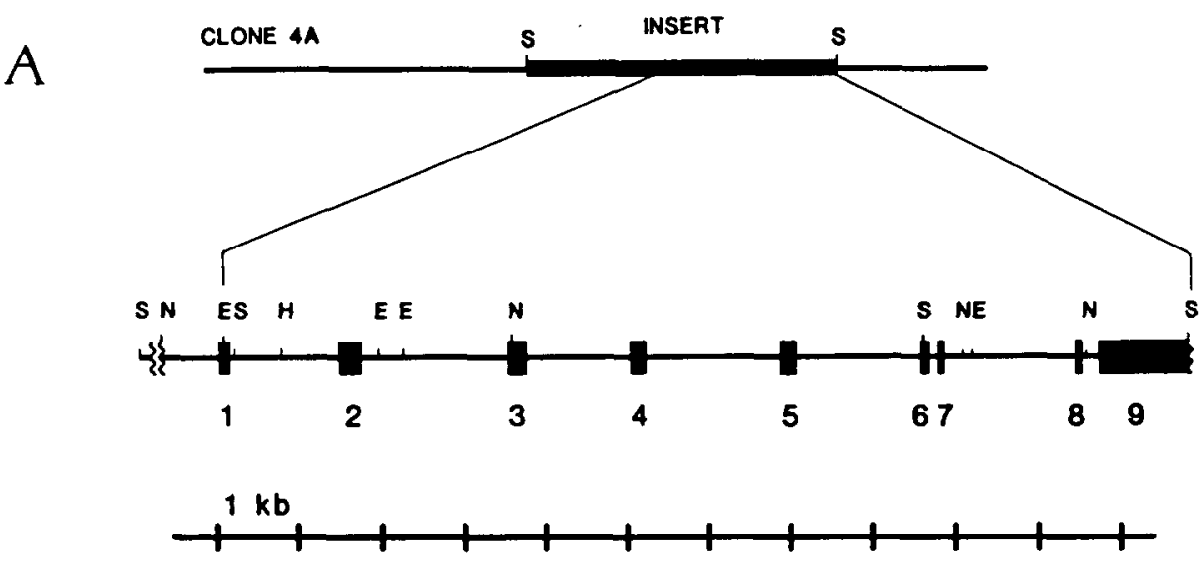

B

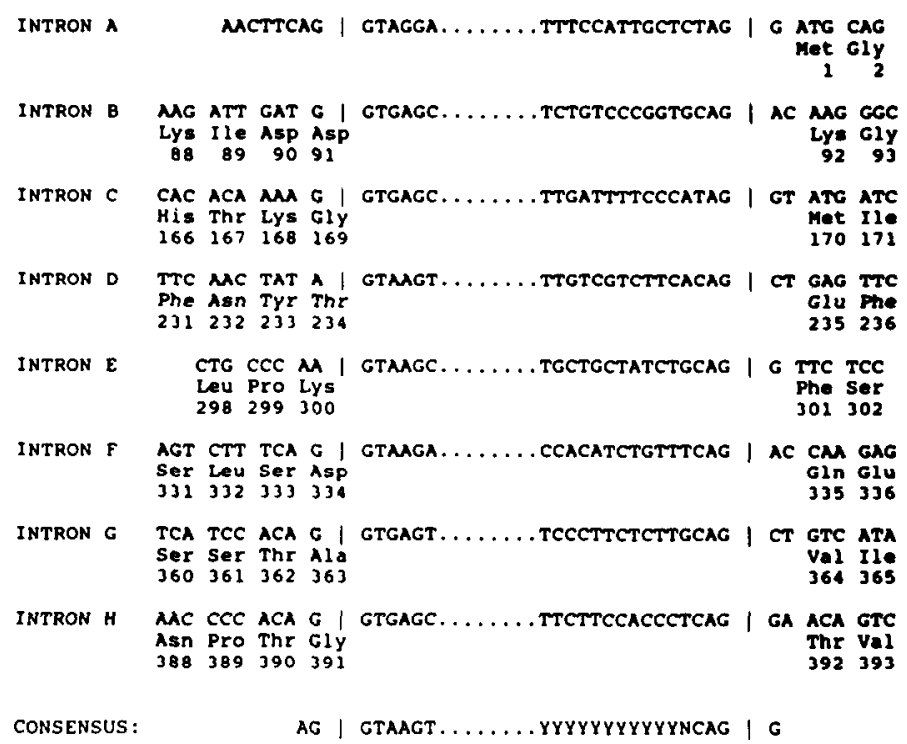

\begin{tabular}{|c|c|c|c|c|c|}
\hline-432 & TTTGATAACT CCACAGTGAC & CTGGTTCGCC & AAAGGAAAAG & CAGGCAACGT & GAGCTETTIT \\
\hline-372 & TTTTTTCTCC AAGCTGAACA & CTAGGGGTCC & TAGGCTTTTG & GGTCACCCGG & CATGGCAGAC \\
\hline-312 & AGTCAACCTG GCAGGACATC & CGgGaGAGAC & Agacacaggc & AGAGGGCAGA & AMGGTCAAGG \\
\hline-252 & GAGGTTCTCA GGCCAAGGCT & ATTGGGGTTT & GCTCAATTGT & TCCTGAATGC & TCTRACACAC \\
\hline-192 & GTACACACAC AGAGCAGCAC & ACACACACAC & ACACACATGC & CTCAGCAAGT & CCCAGAGAGg \\
\hline-132 & GAGGTGTCGA GGGGGACCCG & CTGGCTGTTC & AGACGGACTC & CCAGAGCCAG & TGAGTGGGTG \\
\hline-72 & $\underset{\nabla}{\operatorname{GGGCTGGAAC} \text { ATGAGTTCAT }}$ & CTATTTCCTG & CCCACATCTG & GraTnAMagG & AGGCAGTGGC \\
\hline-12 & CCACAGAGGA GCACAGCTGT & GTTTGGCTGC & AGGGCCAAGA & GCGCTGTCAA & GMAGACCCAC \\
\hline+49 & ACGCCCCCCT CCAGCAGCTG & AATTCCTGCA & GCTCAGCAGC & CGCCGCCAGA & GCAGGACGAA \\
\hline+109 & CCGCCAATCG CAAGGCACCT & CTGAGAACTT & $\begin{array}{r}\text { CAG } \mid \text { GATG } \\
\text { Met }\end{array}$ & & \\
\hline
\end{tabular}

Fig. 1. Structure and sequence of pail gene. (A) Gene structure. Restriction sites are marked above the map. E, Eco RI; H, HindIII; N, NcoI; S, SalI. Exons are numbered from below. Phage clone 4A obtained from a $\lambda E M B L 3$ genomic library encompasses the entire region shown in detail, as well as greater than $8 \mathrm{~kb}$ of upstream sequence. The two flanking SalI sites have been contributed by the phage. (B) PAI-1 intron/exon boundaries. Sequences of the intron/exon splice junctions are shown. Appropriate aa are listed below the codons. The mRNA splicing consensus sequences (Padgett et al., 1986) are shown in the bottom line for comparison. (C) Sequence of the pail promoter region. The TATA box is underlined and in bold type. The major tsp is the adenine residue located under the arrowhead. The possible Z-DNA forming region is also underlined. Met denotes the initiation methionine. The short vertical line indicates the location of intron 1. 
subjected to restriction endonuclease mapping. Clone 4A was found to contain an insert of greater than $19 \mathrm{~kb}$ and was studied in further detail. Exons were located by restriction enzyme mapping and Southern-blot analysis. All of the clones isolated stop at the Sau 3a site approx. $650 \mathrm{bp} 5^{\prime}$ of the distal polyadenylation signal used for the $3 \mathrm{~kb}$ PAI-1 mRNA species. Clone $4 \mathrm{~A}$ extends approx. $8 \mathrm{~kb}$ upstream from the first exon. The structure of clone 4A was confirmed by comparison with Southern blots of human DNA (not shown).

\section{(b) Gene structure}

The human pail gene spans approx. $12 \mathrm{~kb}$ and contains eight introns (Fig. 1a). The locations of exon 4 was deduced using PCR to determine the sizes of introns $\mathrm{C}$ and $\mathrm{D}$. All exons were sequenced in their entirety and the sequence was found to be identical to that of our previously reported cDNA sequence (Ginsburg et al., 1986). The intron/exon boundary sequences are shown in Fig. $1 \mathrm{~b}$ and were found to conform to the known consensus sequences (Padgett et al., 1986). Sequencing differences were seen in the splice acceptor sequences of introns A, D, $E$ and $F$ when compared to Loskutoff et al. (1987), though our sequence agrees completely with that of Bosma et al. (1988) and Strandberg et al. (1988). The 300-bp EcoRI fragment located in intron 3 contains an $A l u$ repeat and is not present in the gene structure of Loskutoff et al. (1987).

An optimal alignment of the PAI-1 protein sequence with that of other members of the serpin family was determined, and the relative locations of the introns were compared. Our results are consistent with those of Strandberg et al. (1988). As previously noted, conservation of intron positions among serpins correlates poorly with aa sequence similarity (Bao et al., 1987). The degree of aa sequence similarity has frequently been used to estimate evolutionary relatedness among proteins. We hypothesize that the presence or absence of introns should be subject to weaker selective pressures than aa sequence, and thus may provide a more reliable measure of evolutionary relatedness within the serpin family than aa sequence. A similar hypothesis was suggested by Ragg and Preibisch (1988) in their analysis of the serpin hLS2.

The $t s p$ for pail transcription was determined by

primer extension and S1 nuclease analysis (Fig. 2). With both methods, the $t s p$ was shown to be $142 \mathrm{bp}$ $5^{\prime}$ of the start codon (Figs. 1c and 2). $432 \mathrm{bp}$ of upstream promoter sequence was determined on

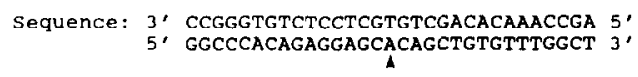

PRIMER EXTENSION

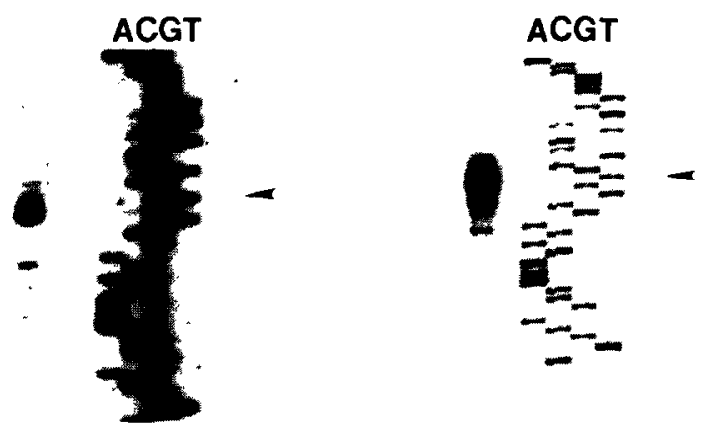

Fig. 2. Mapping of the tsp. Both primer extension and S1 nuclease reactions are shown. The sequence seen in the gels is that of the antisense strand. The sequences of both sense and antisense strands are shown above. Arrowheads indicate the transcription start site. A primary culture of HUVECS (gift of S. Weiss, University of Michigan) was grown and passaged as previously described (Konkle and Ginsburg, 1988). Isolation of total RNA (Strohman et al., 1977) and oligo(dT) cellulose (Collaborative Research) chromatography (Aviv and Leder, 1972) were preformed as described. $\mathbf{S} 1$ analysis was performed as described by Ausubel et al. (1987) with minor modifications. A 17-mer oligo (P1) of sequence 5'-TGGCGGTTCGTCCTGCT and complementary to $\mathrm{nt}+98$ to +115 of pail (Fig. 1c) was used as primer. $6 \times 10^{-4} A_{260}$ units of P1 were end-labeled with T4 polynucleotide kinase (New England Biolabs) and $100 \mu \mathrm{Ci}$ of $\left[\gamma^{32} \mathrm{P}\right]$ ATP $(5000 \mathrm{Ci} / \mathrm{mmol})$ (Amersham). $2.4 \times 10^{5} \mathrm{cpm}$ of gelpurified probe was added to $20 \mu \mathrm{g}$ of total HUVEC RNA and hybridized overnight at $30^{\circ} \mathrm{C}$. Half of the final sample was loaded onto a denaturing $8 \%$ polyacrylamide gel. The size marker for both $\mathrm{S} 1$ nuclease and primer extension analyses was a sequencing reaction using the same end-labeled oligo $P 1$ as primer with plasmid subclone $\mathrm{S} 4$ as template. For the primer extension reaction, $\mathrm{P} 1$ was end-labeled as above and then purified on a $15 \%$ polyacrylamide gel. $1.3 \times 10^{5} \mathrm{cpm}$ of labeled probe (with a spec. act. of approx. $1.5 \times 10^{6} \mathrm{cpm} / \mathrm{mg} \mathrm{DNA}$ ) was added to $2 \mathrm{mg}$ of poly(A) ${ }^{+} \mathrm{mRNA}$, heated at $90^{\circ} \mathrm{C}$ for $2 \mathrm{~min}$, and then incubated for $1.5 \mathrm{~h}$ at $52^{\circ} \mathrm{C}$ in $50 \mathrm{mM}$ Tris $\mathrm{pH} 8 / 50 \mathrm{mM}$ $\mathrm{KCl} / 5 \mathrm{mM} \mathrm{MgCl} / 10 \mathrm{mM}$ dithiothreitol. After cooling slowly to $37^{\circ} \mathrm{C}, 4$ units of AMV reverse transcriptase (Seikagaku America, Inc.) were added and the reaction made $100 \mathrm{mM}$ with respect to dTTP, dCTP, dGTP, and dATP. This mixture was then incubated at $37^{\circ} \mathrm{C}$ for $35 \mathrm{~min}$. An equal volume of formamide loading buffer was then added to the tube, and the products were analyzed by electrophoresis on an $8 \%$ polyacrylamide sequencing gel. 
both strands (Fig. 1c) and consensus promoter elements were noted as previously observed (Bosma et al., 1988 and Fig. 1c).

The location of the pail tsp is consistent with the observation that $A$ residues are the most common nt used at the $t s p$ (Salditt-Georgieff et al., 1980) and that $\mathrm{CA}$ is the most common motif at the cap site (Bucher and Trifonov, 1986). Our results agree with those found by Riccio et al. (1988) in their S1 analyses on a variety of cell types and Strandberg et al. (1988) in S1 analysis of human placenta. Bosma et al. (1988) and Van Zonnefeld et al. (1988) have localized the start $3 \mathrm{nt}$ upstream from this site at an $A$ residue which follows a $G$. In both of our experiments secondary bands became visible upon longer exposure, one of which was located at this second $\mathrm{A}$ residue, possibly representing a weak alternative $t s p$.

\section{(c) Promoter function}

To test whether the region upstream from the pail gene could function as a eukaryotic promoter, an 800-bp NcoI-EcoRI fragment which contained approx. $730 \mathrm{bp}$ of $5^{\prime}$ flanking region was inserted $5^{\prime}$ of the bacterial cat gene in both orientations in the vector pUMSVO. Plasmid pRSVCAT was used as a positive control. The 800-bp EcoRI-NcoI pail fragment was shown to function as a promoter in COS cells only in the correct orientation (Fig. 3). This segment is a much weaker promoter in COS cells than the strong viral promoter of RSV.

Northern-blot analysis of HUVEC and COS total RNA probed with radiolabeled pail cDNA revealed that COS cells contain the PAI-1 message (Fig. 4). The relative amount of PAI-1 in COS cells appears to be substantially lower than that in HUVECs. Since COS cells are derived from the kidney epithelium of the African green monkey (Jensen et al., 1964), these results are consistent with the previous detection of PAI-1 antigen in BSC-1, another monkey kidney epithelial cell line (Thalacker and Nilsen-Hamilton, 1987).

In human cells, PAI-1 mRNA is of two sizes, a smaller 2.3-kb message and a larger 3-kb message. This size difference has been postulated to be due to either differential splicing or to the use of different polyadenylation sites. The absence of an intron at

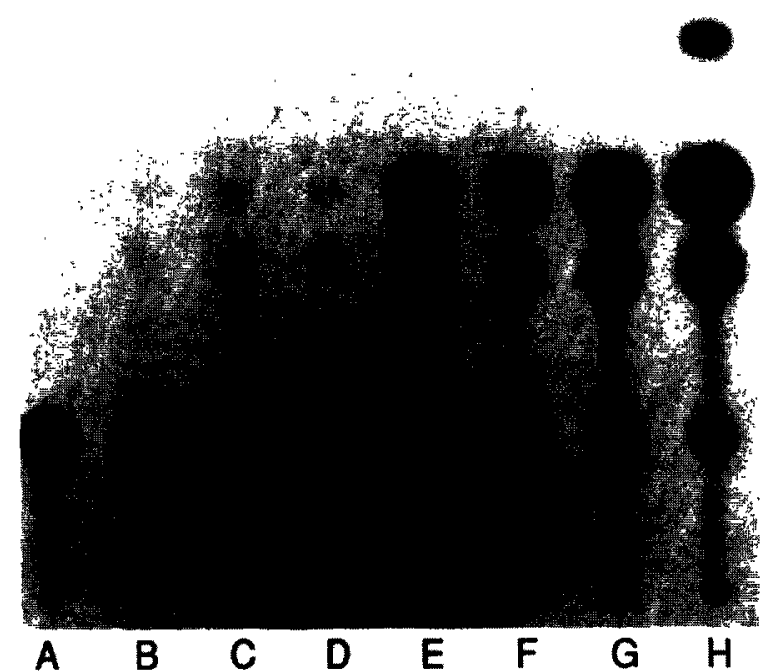

Fig. 3. CAT assays of transfected COS cell extracts. Lanes: A, pSVO; B, pUMSVO (CAT activity normalized for transfection efficiency; 0.81 and 1 respectively); $\mathbf{C}$ and $\mathbf{D}$, duplicate transfections of pail promoter fragment in reverse orientation (CAT activity: $1.11 \pm 0.5$ ); $\mathrm{E}$ and $\mathrm{F}$, duplicate transfections of pail promoter fragment in forward orientation (CAT activity: $18 \pm 7$ ); $\mathrm{G}$ and $\mathrm{H}$, duplicate transfections of pRSVCAT (CAT activity: at least $2890 \pm 686$ ). COS cells were grown and passaged as previously described (Ginsburg et al., 1989). An 800-bp $N c o$ I-EcoRI fragment containing 730 bp of sequence $5^{\prime}$ to the $t s p$ was cloned in both orientations into the vector pUMSVO (Salier and Kurachi, 1989) which contains the bacterial cat gene. Plasmid pRSVCAT (Gorman et al., 1982) was transfected as a positive control. The transfection protocol used was that of Chen and Okayama (1987). Of the test plasmid, $10 \mu \mathrm{g}$ along with $1 \mu \mathrm{g}$ of pRSVGH (Selden et al., 1986) as a transfection control, were added to $100-\mathrm{mm}$ dishes which had been seeded $24 \mathrm{~h}$ earlier with $1 \times 10^{5} \mathrm{COS}$ cells. The amount of growth hormone present $72 \mathrm{~h}$ after transfection was assayed using a commercial kit (Nichols Diagnostics) and following the manufacturer's instructions. CAT assays were performed according to standard procedures (Gorman et al., 1982) with a reaction time of $1 \mathrm{~h}$ for the quantitative comparisons. The amount of protein present in each cell extract was measured using a standard Bradford assay (Bio-Rad) according to the manufacturer's instructions. Amounts of extract normalized for a protein content of $275 \mu \mathrm{g}$ to be used in each CAT assay reaction except for PRSVCAT in which $1 / 10$ of this amount was used. Except for pSVO and pUMSVO, all transfections were done in duplicate. Differences in transfection efficiencies were corrected by normalizing the CAT assay values relative to the growth-hormone assay, with pUMSVO set as 1.0 , and the mean and standard deviation for each were calculated. The reaction shown here was derived from the same cell extracts, and the conditions were identical to those described above except for a reaction time of $2 \mathrm{~h}$, and dilution of pRSVCAT extract to $1: 8$ instead of $1: 10$. The value for pRSVCAT is out of the lincar range for the assay and should be regarded as a minimum estimate. 


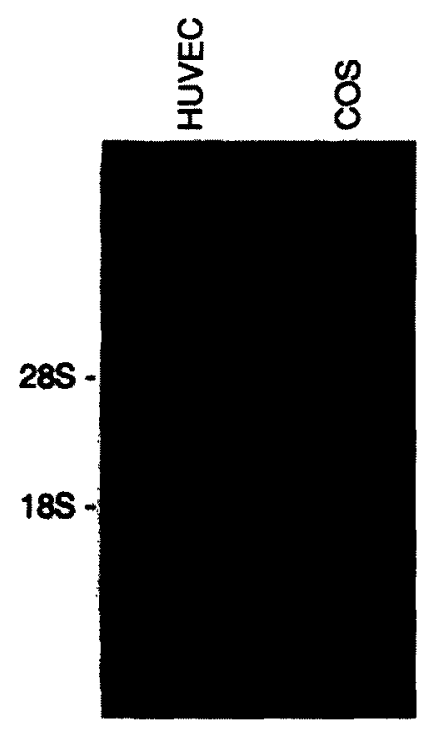

Fig. 4. Northern-blot analysis of total HUVEC and COS cell RNA was performed as described (Ginsburg et al., 1986). The final two washes were in $0.1 \times \mathrm{SSC}$ and $0.1 \% \mathrm{SDS}$ at $68^{\circ} \mathrm{C}$ for $30 \mathrm{~min}$ each. Film was developed after a $16 \mathrm{~h}$ exposure at $-80^{\circ} \mathrm{C}$ with an intensifying screen. The probe used was the same as that used to screen the genomic library. Equal amounts $(10 \mu \mathrm{g})$ of total RNA was loaded on each lane. The quantity of RNA present in each lane appeared equal by the comparison of $18 \mathrm{~S}$ and 28S rRNA bands visualized by ethidium bromide staining (not shown). The locations of the 28S and 18S rRNA bands are indicated.

the end of the $2.3-\mathrm{kb}$ message confirms that this size difference is due to alternative polyadenylation (Loskutoff et al., 1987; Bosma et al., 1988; Strandberg et al., 1988). It is interesting to note that both messages are present in COS cells, as in human cells (Fig. 4). When PAI-1 mRNA has been examined in other species only the larger 3-kb mRNA species is seen [bovine (Sawdey et al., 1986), rat (Zeheb and Gelehrter, 1988), and porcine, (M.F. and D.G., unpublished data)]. Processing at the proximal polyadenylation signal producing the $2.3-\mathrm{kb}$ mRNA species removes an $\mathrm{A}+\mathrm{T}$-rich palindromic sequence which has been hypothesized to play a role in regulating pail gene expression (Ginsburg et al., 1986). The significance of the shorter message observed only in primate species remains to be determined.

\section{ACKNOWLEDGEMENTS}

We would like to thank J. Leiden for his thoughtful review of the manuscript. This work was supported in part by NIH-NHLBI-No. 1-RO1HL39137-01. DG is an investigator of the Howard Hughes Medical Institute.

\section{REFERENCES}

Andreasen, P.A., Riccio, A., Welinder, K.G., Douglas, R., Sartorio, R., Nielsen, L.S., Oppenheimer, C., Blasi, F. and Dano, K.: Plasminogen activator inhibitor type-1: reactive center and amino-terminal heterogeneity determined by protein and cDNA sequencing. FEBS Lett. 209 (1986) 213-217.

Ausubel, F.M., Brent, R., Kingston, R.E., Moore, D.D., Smith, J.A., Seidman, J.G. and Struhl, K.: Current Protocols in Molecular Biology. Wiley, New York, 1987.

Aviv, H. and Leder, P.: Purification of biologically active globin messenger RNA by chromatography on oligothymidylic acidcellulose. PNAS USA 69 (1972) 1408-1412.

Bao, J.-J., Sifers, R.N., Kidd, V.J., Ledley, F.K. and Woo, S.L.C.: Molecular evolution of serpins: homologous structure of the human $\alpha 1$-antichymotrypsin and $\alpha 1$-antitrypsin genes. Biochemistry 26 (1987) 7755-7759.

Bosma, P.J., Van den Berg, E.A., Kooistra, T., Siemieniak, D.R. and Slightom, J.L.: Human plasminogen activator inhibitor-1 gene. J. Biol. Chem. 263 (1988) 9129-9141.

Bucher, P. and Trifonov, E.: Compilation and analysis of eukaryotic POL II promoter sequences. Nucleic Acids Res. 14 (1986) 10009-10026.

Chen, C. and Okayama, H.: High-efficiency transformation of mammalian cells by plasmid DNA. Mol. Cell. Biol. 7 (1987) 2745-2752.

Erickson, L.A., Schleef, R.R., Ny, T. and Loskutoff, D.J.: The fibrinolytic system of the vascular wall. Clin. Haematol. 14 (1985) 513-530.

Feinberg, A.P. and Vogelstein, B.: A technique for radiolabeling DNA restriction endonuclease fragments to high specific activity. Anal. Biochem. 132 (1983) 6-13.

Frischauf, A.-M., Lehrach, H., Poustka, A. and Murray, N.: Lambda replacement vectors carrying polylinker sequences. J. Mol. Biol. 170 (1983) 827-842.

Ginsburg, D., Zeheb, R., Yang, A.Y., Rafferty, U.M., Andreason, P.A., Lebo, R.V. and Gelehrter, T.D.: cDNA cloning of human plasminogen activator-inhibitor from endothelial cells. J. Clin. Invest. 78 (1986) 1673-1680.

Ginsburg, D., Konkle, B.A., Gill, J.C., Montgomery, R.P., Bockenstedt, P.L., Johnson, T.A. and Yang, A.Y.: Molecular basis of human von Willebrand disease: analysis of platelet von Willebrand factor mRNA. Proc. Natl. Acad. Sci. USA 86 (1989) 3723-3727.

Gorman, C.M., Merlino, G.T., Willingham, M.C., Pastan, I. and Howard, B.H.: The Rous sarcoma virus long terminal repeat 
is a strong promoter when introduced into a variety of eukaryotic cells by DNA-mediated transfection. Proc. Natl. Acad. Sci. USA 79 (1982) 6777-6781.

Jensen, F.C., Girardi, A.J., Gilden, R.V. and Koprowski, H.: Infection of human and simian tissue cultures with Rous sarcoma virus. Proc. Natl. Acad. Sci. USA 52 (1964) 53-59.

Klinger, K.W., Winqvist, R., Riccio, A., Andreasen, P.A., Sartorio, R., Nielsen, L.S., Stuart, N., Stanislovitis, P., Watkins, P., Douglas, R., Grzeschik, K.-H., Alitalo, K., Blasi, F. and Dano, K.: Plasminogen activator inhibitor type 1 gene is located at region $\mathrm{q} 21.3-\mathrm{q} 22$ of chromosome 7 and genetically linked with cystic fibrosis. Proc. Natl. Acad. Sci. USA 84 (1987) 8548-8552.

Konkle, B.A. and Ginsburg, D.: The addition of endothelial cell growth factor and heparin to human umbilical vein endothelial cell cultures decreases plasminogen activator inhibitor expression. J. Clin. Invest. 82 (1988) 579-585.

Loskutoff, D.J., Linders, M., Keijer, J., Veerman, H., Van Heerikhuizen, H. and Pannekoek, H.: Structure of the human plasminogen activator inhibitor 1 gene: Nonrandom distribution of introns. Biochemistry 26 (1987) 3763-3768.

Loskutor, D.J., Sawdey, M. and Mimuro, J.: Type 1 plasminogen activator inhibitor. In Coller, B.S. (Ed.), Progress in Hemostasis and Thrombosis, Vol.9. Saunders, Philadelphia, 1989, pp. 87-115.

Maniatis, T., Fritsch, E.F. and Sambrook, J.: Molecular Cloning. A Laboratory Manual. Cold Spring Harbor Laboratory, Cold Spring Harbor, NY, 1982.

Needleman, S.B. and Wunsch, C.D.: A general method applicable to the search for similarities in the amino acid sequence of two proteins. J. Mol. Biol, 48 (1970) 443-453.

Ny, T., Sawdey, M., Lawrence, D., Millan, J.L. and Loskutoff, D.J.: Cloning and sequence of a cDNA coding for the human beta-migrating endothelial-cell-type plasminogen activator inhibitor. Proc. Natl. Acad. Sci. USA 83 (1986) 6776-6780.

Padgett, R.A., Grabowski, M., Konarska, M., Seiler, S. and Sharp, P.A.: Splicing of messenger RNA precursors. Annu. Rev. Biochem. 55 (1986) 1119-1150.

Pannekoek, H., Veerman, H., Lambers, H., Diergaarde, P., Verweij, C.L., Van Zonnefeld, A.-J. and Van Mourik, J.A.: Endothelial plasminogen activator inhibitor (PAI): a new member of the serpin gene family. EMBO J. 5 (1986) 2539-2544.
Ragg, J. and Preibisch, G.: Structure and expression of the gene coding for the human serpin hLS2. J. Biol. Chem. 263 (1988) 12129-12134.

Riccio, A., Lund, L.R., Sartorio, R., Lania, A., Andreasen, P.A., Keld, D. and Blasi, F.: The regulatory region of the human plasminogen activator inhibitor type-1 (PAI-1) gene. Nucleic Acids Res. 16 (1988) 2805-2824.

Salditt-Georgieff, M., Harpold, M., Chen-Kiang, S. and Darnell Jr., J.E.: The addition of $5^{\prime}$ cap structures occurs early in hnRNA synthesis and prematurely terminated molecules are capped. Cell 19 (1980) 69-78.

Salier, J.-P, and Kurachi, K.: A CAT expression vector with virtually no background: pUMSVOCAT. BioTechniques 7 (1989) 30-31.

Sanger, F., Nicklen, S. and Coulson, A.R.: DNA sequencing with chain-terminating inhibitors. Proc. Natl. Acad. Sci. USA 74 (1977) 5463-5467.

Sawdey, M., Ny, T. and Loskutoff, D.J.: Messenger RNA for plasminogen activator inhibitor. Thromb. Res. 41 (1986) 151-161.

Selden, R.F., Howie, K.B., Rowe, M.E., Goodman, H.M. and Moore, D.D.: Human growth hormone as a reporter gene in regulation studies employing transient gene expression. Mol. Cell. Biol. 6 (1986) 3173-3179.

Strandberg, L., Lawrence, D. and Ny, T.: The organization of the human-plasminogen-activator-inhibitor-1 gene: implications on the evolution of the serine-protease inhibitor family. Eur. J, Biochem. 176 (1988) 609-616.

Strohman, R.C., Moss, P.S., Micou-Eastwood, J., Spector, D., Przybyla, A. and Paterson, B.: Messenger RNA for myosin polypeptides: isolation from single myogenic cell cultures. Cell 10 (1977) 265-273.

Thalacker, F.W. and Nilsen-Hamilton, M.: Specific induction of secreted proteins by transforming growth factor-beta and 12-O-tetradecanoylphorbol-13-acetate. J. Biol. Chem. 262 (1987) 2283-2290.

Van Zonnefeld, A.-J., Curriden, S.A. and Loskutoff, D.J.: Type 1 plasminogen activator inhibitor gene: functional analysis and glucocorticoid regulation of its promoter. Proc. Natl. Acad. Sci. USA 85 (1988) 5525-5529.

Zeheb, R. and Gelehrter, T.: Cloning and sequencing of cDNA for the rat plasminogen activator inhibitor-1. Gene 73 (1988) 459-468. 